\title{
ON THE DIRECTION OF REMANENT MAGNETIZATION OF THE QUARTZ PORPHYRY DIKES IN SE FINLAND
}

\author{
K. J. NEUVONEN
}

\begin{abstract}
NEUVONEN, K. J., 1986: On the direction of remanent magnetization of the quartz porphyry dikes in SE Finland. Bull. Geol. Soc. Finland 58, Part 1, 195-201.

Attempts are made to determine the direction of remanent magnetization of the rapakivi varieties belonging to the Wiborg (Viipuri) rapakivi massif and its satellites in the precambrian Baltic Shield. Hard and stable remanence was found only in the quartz porphyry dikes which are closely associated with the rapakivi granites and have a radiometric U-Pb age about $1630 \mathrm{Ma}$. The magnetization found evidently represents the direction of the geomagnetic field prevailing during the late phase of the evolution of the rapakivi magma. The calculated paleomagnetic pole site $\left(30^{\circ} \mathrm{N}, 175^{\circ} \mathrm{E}\right.$ with $»$ normal» polarity) agrees well with those previously reported for rocks of about the same age in the Baltic Shield.
\end{abstract}

Key words: paleomagnetism, polar wander curve, rapakivi, Precambrian (1630 Ma).

K. J. Neuvonen: Institute of Geology, University of Turku, SF-20500 Turku, Finland.

\section{Introduction}

In constructing the apparent polar wander curve for the Fennoscandian (Baltic) Shield, Pesonen and Neuvonen (1981) accepted the »subJotnian loop») in the polar path originally proposed by Pesonen (1979). The rapakivi intrusions in Finland and Sweden were emplaced and cooled during this sub-Jotnian time so that well dated paleomagnetic data of these rocks would, therefore, give additional information needed to verify or modify the shape of the loop drawn.

More than 250 oriented core samples were drilled during the last five years from a wide variety of rapakivi types in order to determine the direction of the remanent magnetization in the rocks belonging to the Wiborg massif (Wahl, 1925) and its satellites. Most of these rocks were, however, too weakly magnetized to be measured with the fluxgate spinner magnetometer available or were too unstable to give any reliable results. Some rock types, like the dark, sometimes fayalite containing variety, »tirilite» (Wahl, 1925), has a fairly stable component of magnetization which is subparallel to the present geomagnetic field. This magnetization is assumed to be caused by a late chemical remanence associated with the intense weathering so typical for rapakivi granites.

Finally, quartz (granite) porphyre dikes were also sampled. These dikes are known to be genetically and spatially connected with the rapa- 
kivi granits. The natural remanent magnetization (NRM) found in these samples is weak but quite stable. The fine grained, chilled margins carry the strongest remanence.

\section{The porphyry dikes}

There are three rapakivi massifs in the southeastern part of Finland (Fig. 1). By far the largest is the $150 \mathrm{~km}$ broad Wiborg rapakivi massif (Wahl, 1925) which lies in the southeastern corner of Finland and extends from the coast of Gulf of Finland c. $90 \mathrm{~km}$ north inland. The other two, Ahvenisto (Savolahti 1956) and Suomenniemi massifs (Frosterus 1902, Simonen and Tyrväinen 1981) are smaller satellites north of the large Wiborg massif. Porphyry dikes are met along the border zone of the rapakivi massifs. Most of them occur around the Suomenniemi and Ahvenisto massifs. The dikes cut through the country rock and into the rapakivi granites as well (Fig. 1). The type of occurrence and the petrography of these dikes are described in detail by Frosterus (1902) and by Savolahti (1956).

The rock type varies very little from dike to dike. Fine grained but wholly crystalline groundmass contains large $(1-4 \mathrm{~cm})$ orthoclase and quartz (less than $1 \mathrm{~cm}$ ) phenocrysts. Small plagioclase phenocrysts are met only sporadically. Biotite occurs as clusters which in some cases can be assumed to be old phenocrysts. The rock has accordingly and with good reason been called granite porphyry (e.g. Savolahti 1956). In many dikes, however, biotite is met only as a groundmass mineral.

Most of the dikes run roughly in SE-NW direction, are $\mathbf{1} \mathbf{- 3 0}$ meters wide, and have a chilled, fine grained contact zone which occurs also against the rapakivi granite.

The groundmass consists of potassium feldspar, quartz and plagioclase. In addition there are biotite and frequently some fluorite and apatite. The remanence is carried by magnetite as indicated by thermal and AF demagnetization. Magnetite is met as fine laths within the biotite clusters, as small needles in the groundmass or some times as large euhedral crystals in which the ilmenite lamells have changed into a mixture of sphene and limonite (goethite). All these magnetite types are assumed to be of the same age. Evidently, to some extent, a component of the remanent magnetization is carried also by the hydrous iron oxide pigment quite abundant in some samples.

\section{The age of the dikes}

The dikes penetrate with chilled margins into the rapakivi massif. They must, therefore, be considerably younger than the main rapakivi types. Evidently, the porphyry dikes represent the latest phase in the evolution of the rapakivi magma in the area. According to Savolahti (1956, p. 75) some quartz porphyry dikes are, however, cut by still younger pegmatite veins. Based on radiometric $\mathrm{U}-\mathrm{Pb}$ measurements on zircon, Vaasjoki (1977) suggested tentatively that the main magmatic phase occurred at $1700-1660 \mathrm{Ma}$ in the southern, northern and northwestern part of the Wiborg massif and in the Suomenniemi satellite and at 1660-1640 Ma in the northeastern part of the main Wiborg massif and in the Ahvenisto satellite. The Kymi granite cupola, at the southern border of the Wiborg massif was accordingly supposed to be $1640 \mp 15 \mathrm{Ma}$ old.

Vaasjoki (1977) measured also samples from the Mentula and Hamina porphyry dikes but obtained for them ages older than those of the main rapakivi granites. According to the clear field evidence, however, the porphyry dikes are cutting the other rapakivi types and thus must be younger than these. Later, additional radiometric

Fig. 1. Rapakivi massifs and quartz porphyry dikes in SE Finland. Based mainly on the maps of rocks by the Geological Survey of Finland, $1: 100000$. 


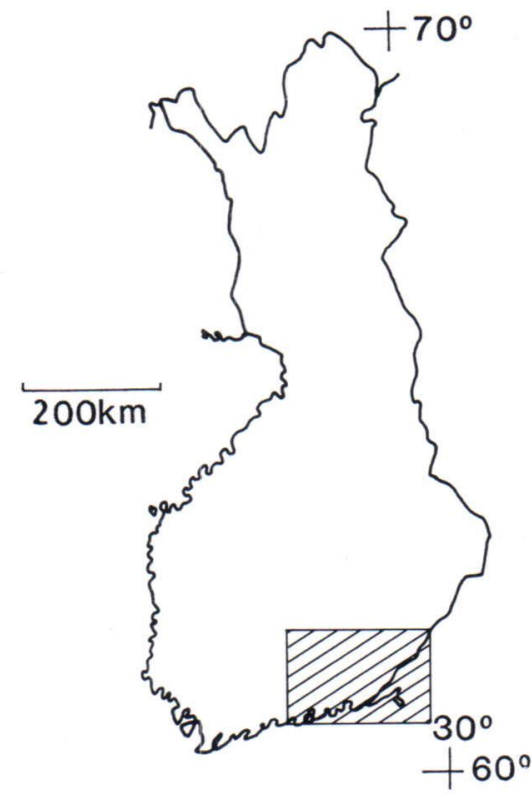

\section{RAPAKIVI MASSIFS OF SE-FINLAND AND}

ASSOCIATED QUARTZ PORPHYRY DIKES

$\square$ Rapakivi

$\longrightarrow$ Quartz porphyry dike with collected samples

\section{Country rock}

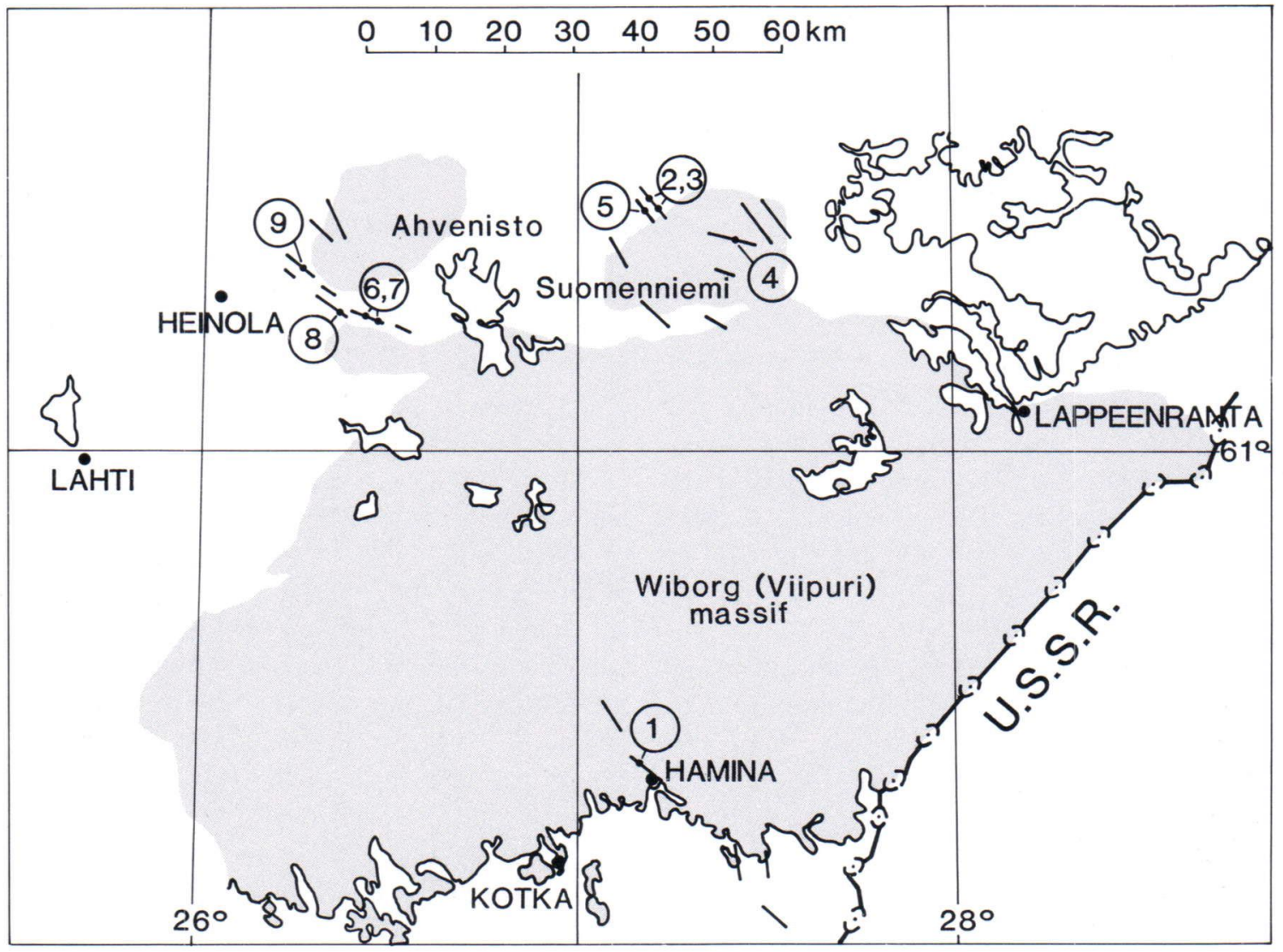




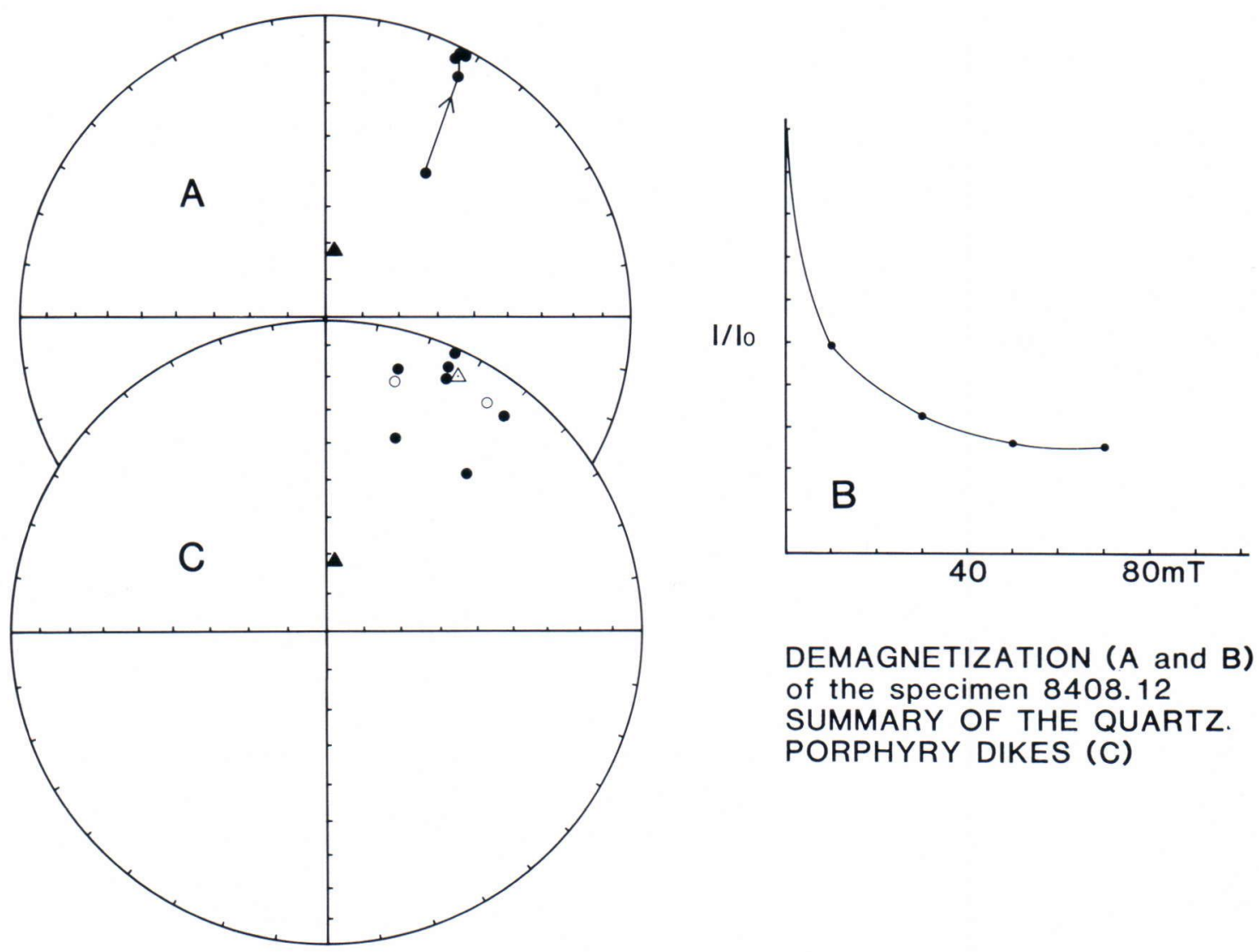

Fig. 2. AF demagnetization (A and B) and summary of the directions of the remanent magnetization of the quartz porphyry dikes (C). positive and Onegative inclination. Open triangle $=$ the mean direction, closed one $=$ present geomagnetic field direction (PEF).

measurements were made on the Hamina porphyry dike in the age laboratory of the Geological Survey (Kouvo 1983) using hand-picked and carefully preleached zircon fractions. An upper condordia intercept corresponding to the age 1617 × $2 \mathrm{Ma}$ was obtained. Ages $1639 \mp 9 \mathrm{Ma}$ for Mentula and 1638 ₹ 53 Ma for Kiesilä porphyry dikes were measured using normal and preleached fractions (a personal communication by O. Kouvo, 1984). These radiometric zircon ages (on an average $1631 \mathrm{Ma}$ ) are in good harmony with the contact observations on the field and support the idea that quartz porphyry dikes represent the late phase in the evolution of the rapakivi magma in this area.

\section{Paleomagnetic samples and measurements}

Altogether 26 sun oriented quartz porphyry core samples were drilled on 10 sites for the present study (Fig. 1). Samples on 9 sites carried a remanence strong enough to be measured and to enable an AF cleaning. The measurements were made with a low speed $(6 \mathrm{~Hz})$ spinner magnetometer with four fluxgate sensors. For washing out the (VMR) magnetization, a commercial single axis (Schoenstedt GSD-1) instrument and a home made demagnetization furnace with a triple mu-metal shielding were employed. Secondary magnetization was removed by a stepwise demagnetization and a stable direction of rema- 
nence was obtained at $30-70 \mathrm{mT}$ peak fields (Fig. $2 \mathrm{~A}$ and B). High alternating fields (over $70 \mathrm{mT}$ ) caused the remanence to diminish under the noise level of the fluxgate instrument. During the heating experiments, the direction of the magnetization first turned towards the same direction as in the AF treatment but at temperatures above 300 degrees parasitic, laboratory produced magnetization made further measurements impossible. This magnetization was evidently caused by dehydration and recrystallization of the hydrous iron oxide pigment frequently met in these specimens.

Table 1 lists the direction of the remanent magnetization after AF demagnetization at $70 \mathrm{mT}$ peak field. Fig. $2 \mathrm{C}$ shows the scatter in the results. The apparent paleomagnetic pole position calculated by means of the average direction
(Fisher, 1953) is shown in Fig. 3 together with the APW path of the Baltic Shield as constructed by Pesonen and Neuvonen (1981).

\section{Discussion}

The paleomagnetic pole position calculated for the porphyry dikes (Lat. $30^{\circ} \mathrm{N}$, Long. $175^{\circ} \mathrm{E}$, $\mathrm{dp}=6.6^{\circ}, \mathrm{dm}=13.3^{\circ}$ ) can not be considered to be very well defined. As seen in Table 1, the consistency between the different sample localities as well as between the individual core samples on each sample station is quite poor. The large scatter observed (Fig. 2 C) can be due to a large secular variation during the intrusion of the dikes, but it can also be caused by the fact that the specimens were weak and difficult to

Table 1. Remanent magnetization of quartz porphyry dikes in SE-Finland after AF demagnetization at $70 \mathrm{mT}$ peak field.

\begin{tabular}{|c|c|c|c|c|c|c|c|c|}
\hline $\begin{array}{l}\text { Site } \\
\text { No }\end{array}$ & Locality & $\mathrm{B} / \mathrm{N}$ & Decl. & Incl. & $\begin{array}{c}\text { Intens. } \\
(\mathrm{A} / \mathrm{m}) \times 1000\end{array}$ & A95 & $\mathrm{R}$ & $\mathrm{K}$ \\
\hline 1 & $\begin{array}{l}\text { Kellomäki, } \\
\text { Hamina }\end{array}$ & 3 & $25.3^{\circ}$ & $2.7^{\circ}$ & 1.557 & $4.2^{\circ}$ & 2.9977 & 867.4 \\
\hline 2 & $\begin{array}{l}\text { Mentula S, } \\
\text { Suomenniemi }\end{array}$ & 3 & $25.6^{\circ}$ & $12.2^{\circ}$ & .162 & $25.8^{\circ}$ & 2.9165 & 23.9 \\
\hline 3 & $\begin{array}{l}\text { Mentula N, } \\
\text { Suomenniemi }\end{array}$ & 2 & $39.8^{\circ}$ & $11.0^{\circ}$ & .554 & - & 1.8684 & 7.60 \\
\hline 4 & $\begin{array}{l}\text { Kiesilä, } \\
\text { Savitaipale }\end{array}$ & 2 & $15.5^{\circ}$ & $14.3^{\circ}$ & .480 & - & 1.7887 & 4.733 \\
\hline 5 & $\begin{array}{l}\text { Viiru, } \\
\text { Suomenniemi }\end{array}$ & 3 & $15.0^{\circ}$ & $-18.5^{\circ}$ & .576 & $34.4^{\circ}$ & 2.8562 & 13.91 \\
\hline 6 & $\begin{array}{l}\text { Ansalahti, } \\
\text { Jaala }\end{array}$ & 2 & $41.8^{\circ}$ & $33.6^{\circ}$ & .425 & - & 1.9452 & 18.40 \\
\hline 7 & $\begin{array}{l}\text { Ansalahti W, } \\
\text { Jaala }\end{array}$ & 2 & $35.3^{\circ}$ & $-12.1^{\circ}$ & .363 & - & 1.9909 & 110.0 \\
\hline 8 & $\begin{array}{l}\text { Rihu, } \\
\text { Heinola }\end{array}$ & 2 & $24.6^{\circ}$ & $8.3^{\circ}$ & .160 & - & 1.8661 & 7.470 \\
\hline 9 & $\begin{array}{l}\text { Ruukinjärvi, } \\
\text { Heinola }\end{array}$ & 2 & $19.8^{\circ}$ & $35.1^{\circ}$ & .532 & - & 1.9609 & 25.55 \\
\hline $\begin{array}{l}\text { Mean } \\
\text { Lat. } \\
\text { Long. }\end{array}$ & $\begin{array}{l}61.25^{\circ} \mathrm{N} \\
26.83^{\circ} \mathrm{E}\end{array}$ & $9 / 21$ & $26.9^{\circ}$ & $9.9^{\circ}$ & .534 & $13.2^{\circ}$ & 8.5061 & 16.20 \\
\hline $\begin{array}{l}\text { Paleomag } \\
\text { Lat. }\end{array}$ & $\begin{array}{l}\text { tic pole position } \\
30^{\circ} \mathrm{N} \text {, Long. }\end{array}$ & , dP & $6.6^{\circ} \mathrm{dl}$ & $13.3^{\circ}$ & & & & \\
\hline
\end{tabular}

Notes: $\mathrm{B}$ is the number of core samples and $\mathrm{N}$ the number of sample sites averaged, A95 is the radius of the cone of $95 \%$ confidence, $R$ is the resultant unit vector, $k$ is precision parameter $(N-1) /(N-R)$, $d p$ and dm are the semiaxes of the oval of $95 \%$ confidence about the paleopole. 


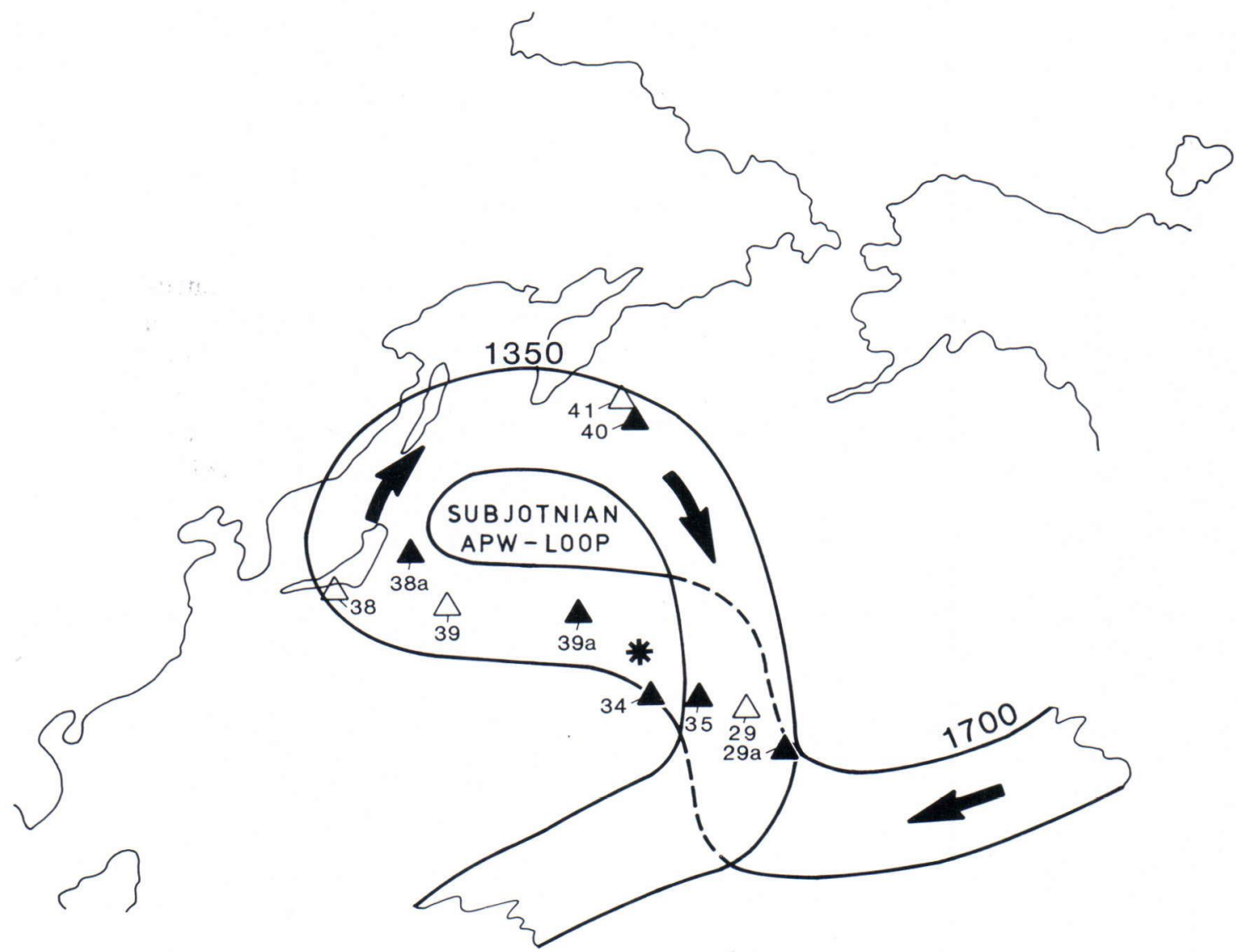

Fig. 3. Paleomagnetic pole positions.

Star = paleopole of the quartz porphyry dikes (this study). APW path for the Baltic Shield after Pesonen and Neuvonen (1981), "The sub-Jotnian Loop».

Triangles $=$ paleopoles of rapakivi intrusion in part recalculated by Pesonen and Neuvonen (1981) in constructing the APW curve: (29) Kuisaari baked contact rock (Neuvonen 1978), (29 a) Åland rapakivi (Johnson 1979), (34) Loftahammar gabbro (Poorter 1976), (35) Dala porphyries (Mulder 1971), (38, 38 a and 39) Nordingrå gabbro-anorthosite and granite intrusions (Piper 1980), (39 a) Gävle granite (Piper 1980), (40, 41) Ragunda intrusive rocks (Piper 1979). Open triangles $=$ reversed polarity, closed ones normal polarity.

measure with the magnetometer available. Considering the discrepancy involved, the average direction and the calculated pole position are, however, reasonable and therefore thought to be of interest.

As seen on the Fig. 3 the paleopole calculated lies well on the APW path drawn for the Baltic Shield. For comparison, the previously known rapakivi pole positions are plotted in the same figure. The pole based on the present data lies in the middle between the Swedish (Nos 3439 a) and the two Finnish poles ( 29 and 29 a).
Based on available radiometric age data, the Swedish rapakivi poles are somewhat younger than the Finnish ones. Pole 34 belongs to the Loftahammar gabbro but the age of this intrusion is somewhat unclear (Poorter 1976, Lundqvist 1979). The pole No 35 is the paleopole calculated for the Swedish Dala porphyries which are about of the same age (1635 Ma, Welin and Lundqvist, 1970) as the porphyry dikes in SE Finland. The southern part of the loop drawn includes thus the rapakivi poles in correct age order: older Finnish poles in the east and younger 
Swedish poles in the western part. Poles 40 and 41 belong to Swedish Ragunda rapakivi intrusions which evidently are much younger (about $1320 \mathrm{Ma}$ ) than the rest of the sub-Jotnian poles plotted in the figure. Some of the poles concerned are normal and some reversed indicating existence of alternating polarity intervals during the sub-Jotnian time. All the porphyry dikes in the present study had normal polarity but there are some amphibolite inclusions in the Wiborg rapakivi which have a reversed direction of remanent magnetization (unpublished).

Present observations together with paleomagnetic pole positions determined earlier on subJotnian rapakivi intrusions in the Baltic Shield (Fig. 3) lead us to the following conclusions:

1) Most of the poles lie on the southern limb of the APW loop so that this part of the curve must be considered to be fairly correct (age labels along the APW path might need some adjustment).

\section{References}

Fisher, R. A., 1953. Dispersion on a sphere. Royal Soc. London Proc. Ser. A, 217, 295-305.

Frosterus, Benj., 1902. Beskrifning till bergartskartan C 2, S:t Michel. Resume en Francais. Geological Map of Finland, $1: 400000$.

Johnson, P. W., 1979. A paleomagnetic Study of Precambrian Rocks from S.W. Finland. M.Sc. Thesis, Univ. Newcastle-upon-Tyne, 43 pp. (unpubl.).

Kouvo, Olavi, 1983. Isotooppigeologiset tutkimukset. In Ilkka Laitakari (Editor), Kallioperäosaston toimintakertomus vuodelta 1983. Geological Survey of Finland, 39-51.

Lundqvist, Thomas, 1979. The Precambrian of Sweden. Sveriges Geol. Undersökning, Ser. C 768, 87 pp.

Mulder, F. G., 1971. Paleomagnetic research in some parts of central and southern Sweden. Sveriges Geologiska Undersökning, Ser. C. 653, 56 pp.

Neuvonen, K. J., 1978. Remanent magnetization of two intrusive bodies in southeastern Finland. Bull. Geol. Soc. Finland $50,31-37$.

Pesonen, L. J., 1979. Mannerlaattojen liike prekambrisena aikana - paleomagneettisia esimerkkejä Kanadan ja Baltian kilvistä. Geologi, 31 (8), 118-122 (in Finnish with English abstract and figure captions).

Pesonen, L. J. \& Neuvonen, K. J., 1981. Palaeomagnetism of the Baltic Shield - Implications for Precambrian
2) the Finnish and the Swedish poles lie close together indicating that there has not been any major lateral displacement between these blocks since the sub-Jotnian time.

3) the younger (northern) part of the polar loop is less well documented and the shape of $» s u b-$ Jotnian Loop» remains uncertain and needs more well dated paleomagnetic data. Rocks of suitable age are not easily found in the Finnish part of the Baltic Shield but might well be available in Sweden.

4) the existence of both polarities in NRM in these rocks might in future turn out to be a useful tool in correlating rock from the subJotnian period.

Acknowledgements. The author thanks Olavi Kouvo, Ilkka Laitakari and Aimo Tyrväinen for the help in finding the dikes and good sampling sites. Especial thanks are due to Olavi Kouvo for the additional age runs and to Lauri Pesonen who read the manuscript and made valuable suggestions. The figures were kindly drawn by Mrs. Tarja Hiltunen.

Tectonics. In A. Kröner (Editor), Precambrian Plate Tectonics. Elsevier, Amsterdam, 623-648.

Piper, J. D. A., 1979. Paleomagnetism of the Ragunda intrusion and dolerite dykes, central Sweden. Geol. Fören. Stockholm Förh., 101, 139-148.

—, 1980. Palaeomagnetic study of the Swedish Rapakivi suite: Proterozoic tectonics of the Baltic Shield. Earth Planet. Science Letters 46, 443-461.

Poorter, R. P. E., 1976. Paleomagnetism of the Svecofennian Loftahammar gabbro and some Jotnian dolerites in the Swedish part of the Baltic Shield. Phys. Earth Planet. Inter. 12, 241-247.

Savolahti, Antti, 1956. The Ahvenisto massif in Finland. Bull. Comm. Geol. Finlande 174, 96 pp.

Simonen, Ahti \& Tyrväinen, Aimo, 1981. Kallioperäkartan selitys 3132, Savitaipale. English summary: Explanation to the map of rocks, $29 \mathrm{pp}$.

Wahl, Walter, 1925. Die Gesteine des Wiberger Rapakiwigebietes. Fennia 45, No 20, 127 pp.

Vaasjoki, Matti, 1977. Rapakivi granites and other postorogenic rocks in Finland: their age and the lead isotopic composition of certain associated galena mineralization. Geol. Survey Finland, Bull. 294, 64 pp.

Welin, E. \& Lundqvist, Th., 1970. New Rb-Sr age data for the sub-Jotnian volcanics (Dala porphyries) in the LosHamra region, central Sweden. Geol. För. i Stockholm Förhandl. 92, 35-39. 